Article

\title{
Scale Effects of Ecological Safety of Water-Saving Irrigation: A Case Study in the Arid Inland River Basin of Northwest China
}

\author{
Guangyu Jiang ${ }^{1}$ and Zhongjing Wang ${ }^{1,2,3, *}$ \\ 1 Department of Hydraulic Engineering, Tsinghua University, Beijing 100084, China \\ 2 State Key Laboratory of Hydroscience and Engineering, Tsinghua University, Beijing 100084, China \\ 3 State Key Laboratory of Plateau Ecology and Agriculture, Qinghai University, Xining 810016, China \\ * Correspondence: zj.wang@tsinghua.edu.cn; Tel.: +86-010-62782021
}

Received: 28 July 2019; Accepted: 5 September 2019; Published: 11 September 2019

\begin{abstract}
Water cycles exist in all processes of water resources utilization, including water-saving irrigation. Due to the complex water cycle process of irrigation, the ecological effects and safety of large-scale water-saving irrigation have received increasing attention. This paper analyzed both the positive and negative ecological effects of water-saving irrigation and the scale effects from the plant-scale to the watershed-scale. Based on the Vensim and GMS (Groundwater Modeling System) models, a quantitative evaluation method of ecological safety of large-scale water-saving irrigation was proposed. The case study in Changma Irrigation District in the arid inland river basin of Northwest China showed that the ecological safety of large-scale water-saving irrigation was sensitive to the combination of water source condition, water distribution technology and water-saving irrigation technology in field. In terms of the positive effects, large-scale water-saving irrigation can reduce the percolation loss of irrigation water, increase the environment water flow for the downstream, and slow down the salinity accumulation. As for the negative effects, large-scale water-saving irrigation could reduce the groundwater recharge, decrease the environment water supply in local farmland, and cut down the soil salinity leakage. The research results have positive significance for guiding the sustainable development of water-saving irrigation and conservation of ecosystem in an arid inland river basin.
\end{abstract}

Keywords: large-scale water-saving irrigation; scale effects; ecological safety evaluation; simulation model; Shule River Basin

\section{Introduction}

Water is one of the fundamental natural resources for human society and economic development, and is also the basic key factor for ecological and environmental systems. With the rapid growth of population and economic development, water shortage is becoming more and more serious. According to the United Nations World Water Development Report 2018, the global demand for water resources is growing at a rate of $1 \%$ per year, current global water demand is estimated to be approximately $4600 \mathrm{~km}^{3}$ per year and projected to increase by $20-30 \%$ to between 5500 and $6000 \mathrm{~km}^{3}$ per year by 2050 [1]. Irrigation is the largest water consumption over the world, but there is still much room for improvement in agricultural water efficiency. One of the effective ways to alleviate the contradiction between water supply and demand is to develop water-saving irrigation [2]. Jaegermeyr et al. [3] reported that sprinkler irrigation and drip irrigation can reduce non-beneficial consumption by $54 \%$ and $76 \%$ at a river basin scale compared to surface irrigation systems, while maintaining the current level of crop yields. Thompson et al. [4] found that drip irrigation can effectively alleviate the problem 
of water shortages in the Western USA, it can be used in the field for 20 years or more if installed and maintained properly, and the water use efficiency exceeds $85 \%$. Water-saving irrigation aims at obtaining efficient use of precipitation and irrigation water according to crop water demand rules and local water supply conditions. It can be generally divided into engineering technologies, agronomic technologies and management technologies. This paper focused on the engineering technologies, including canal lining, pipeline water delivery, and water-saving technologies in the field, such as drip irrigation and sprinkler irrigation.

Water-saving irrigation can effectively alleviate the water shortage situation, expand the irrigation area, and increase the agricultural output. However, the water-saving irrigation may produce various direct and indirect positive and negative effects on the ecological environment of farmland. Qi and Pang [5] noted that various types of water-saving measures will affect the process of farmland hydrological cycle, affecting the rainfall runoff condition and infiltration process. Lei et al. [6] reported that water-saving irrigation will affect the water environment, soil properties, and biodiversity of the irrigation district, and the environmental effects at the scale of field and irrigation district are different. On the one hand, water-saving irrigation can produce many positive ecological benefits. It can effectively improve the ecological environment of irrigation district and adjacent areas by inhibiting $\mathrm{CH}_{4}$ emissions in paddy fields, such as intermittent irrigation [7,8]. The continuous development of irrigated areas caused by population growth has increased the amount of groundwater exploitation, and water-saving irrigation can significantly reduce the irrigation quota and restore the groundwater level to improve the ecological environment [9]. Frequent applications and appropriate amounts of chemical fertilizers and pesticides in drip irrigation can reduce the non-point source pollution [10]. Yue et al. [11] found that water-saving irrigation measures can reduce the amount of surface water diversion by $52 \%$, which is conducive to increasing river flow and improving river ecology. Pereira et al. [12] reported that the waterlogging and soil salinization problems caused by excessive irrigation quota can be alleviated by water-saving irrigation due to the reduced percolation. On the other hand, if the water-saving irrigation technologies are used improperly or exceed the safe scale thresholds, it will bring a series of ecological risks and lead to the deterioration of the ecological environment in the irrigation district. Canal lining, pipeline water delivery, and the reduction of the irrigation quota in the field will lead to the decline of the groundwater level in the irrigation district, affecting the habitat structure of the canal system and the living environment of the natural vegetation dependent on the groundwater level [11]. With the large-scale implementation of sprinkler or drip irrigation, many canals were abandoned, which caused the degradation of the farmland shelterbelt [13]. Long-term use of drip irrigation will result in an accumulation of salt, triggering the risk of secondary salinization of the soil [14]. In addition, large-scale water-saving irrigation will change the microclimate in the field, such as sprinkler irrigation may lead to the occurrence of wet pests and diseases in the field, while drip irrigation may cause plagues of locusts [15]. Grafton et al. put forward the "paradox of irrigation efficiency" and reported that water-saving irrigation may increase the total water consumption of agriculture, and the reduction in recoverable return flows will cause groundwater degradation, loss of aquatic ecosystems, reduction of environmental water, and the reduction of salt leaching [16]. In a word, the ecological safety of large-scale water-saving irrigation has aroused increasing attention.

Therefore, it is of great theoretical and practical significance to reasonably evaluate the ecological safety of irrigation district under large-scale water-saving irrigation condition. In this paper, the ecological safety of water-saving irrigation is defined as the health state of the ecological environment of the soil, surface water, groundwater, and biology subsystems in the water-saving irrigation district. However, most studies on the ecological safety of farmland ecosystems focused on the water security and food security, the pollution of pesticides, fertilizers, agricultural membranes and heavy metals, and the living conditions and evolution trends of plants and animals in irrigation districts. Hanjra and Qureshi [17] reported the current and future global situation of water and food from the perspective of supply and demand, and their impact on food security in the context of climate change. Jiang [18] analyzed emerging challenges to water security from climate change, population growth, and rapid 
urbanization, and the water-food-energy nexus, and discussed the current achievements, government actions, and policy initiatives on water security. Stoate et al. [19] outlined the impacts of policy changes on the ecological status of agricultural system across European Union, and noted the production intensification and farmland abandonment had impaired the soil, water, and air conditions and reduced biodiversity in the irrigation district. Shen et al. [20] investigated and evaluated the heavy metal pollution of farmland soils in mining cities, analyzed the concentrations of various heavy metals in the soil, and their carcinogenic risk index for adults and children. Based on monitoring data of bird and high-resolution data on agricultural land use, Jerrentrup et al. [21] discovered that trends of farmland birds were negatively correlated with the increasing maize planting at landscape scale. Kleczkowski et al. [22] combined ecological models with economic analysis to study the effects of pesticide use on wild and commercial bees, and found that the local wild bees were at risk of extinction. Agro-environmental programs in various EU countries aimed at reducing nutrient and pesticide emissions, conserving biodiversity, restoring landscapes, Kleijn and Sutherland [23] described the impacts of various programs on biodiversity. Cole et al. [24] collected 68 species of ground beetles from Scottish farmland habitats and used multivariate analysis to study the impact of agricultural land use and management intensity on these ecological groups. There are few quantitative studies on the ecological safety of irrigation district under the influence of large-scale water-saving irrigation, especially in the arid inland river basin. In terms of research methods, the water cycle simulation models of the irrigation district are widely used because it can comprehensively reflect the process and detail characteristics of the hydrological response. In order to better simulate the complex exchange process between surface water and groundwater, many studies have coupled the surface water models with groundwater models. Aliyari et al. [25] proposed an updated version of the SWAT-MODFLOW model that can be applied to large agro-urban river basins in semi-arid areas, and the results were satisfactory in terms of simulating streamflow and groundwater levels. Hadded et al. [26] developed a decision support system in Southeastern Tunisia by combining WEAP and MODFLOW models, and demonstrated that sea water desalination plants can decrease the drawdown of aquifer. Xu et al. [27] coupled the ArcInfo Geographic Information System with the MODFLOW model to evaluate the impact of irrigation water-saving measures and groundwater abstraction on groundwater dynamics in the irrigation district. However, many models lack flexibility when simulating irrigation areas with complex canal structures, and the Vensim model uses graphical programming to build models that can be easily modified by users based on the specific conditions of different study areas [28,29]. GMS is a groundwater numerical simulation system with multiple calculation modules and various auxiliary modules, which has unified model construction, parameter assignment, geostatistics, result analysis and other pre-processing and post-processing functions, and has been widely used [30,31]. Therefore, this study combined the Vensim and GMS models to construct a simulation model for the study area.

This paper analyzed the positive and negative ecological effects of water-saving irrigation and the scale effects at different scales, discussed the ecological safety of large-scale water-saving irrigation under different water sources and groundwater levels, and proposed a quantitative evaluation method of ecological safety based on Vensim and GMS models. Then, Changma Irrigation District in the arid inland river basin of Northwest China was taken as an example to carry out the ecological safety evaluation of large-scale water-saving irrigation. The ecological safety of large-scale water-saving irrigation scenarios composed by different water source conditions, water distribution technologies, and water-saving irrigation technology in the field were quantitatively analyzed.

\section{Materials and Methods}

The flow chart of methodology is shown in Figure 1. The data required mainly includes the climate and geography, irrigation system, surface water, and groundwater conditions in the study area. The research methods in this paper include two parts: theoretical analysis, and model simulation and calculation. Through the theoretical analysis, the positive and negative ecological effects of water-saving irrigation and the ecological safety at different application scales were analyzed. Based on the Vensim and GMS models, and the proposed quantitative evaluation method of ecological safety 
in irrigation district, the ecological safety of four typical large-scale water-saving irrigation scenarios in the study area was studied.

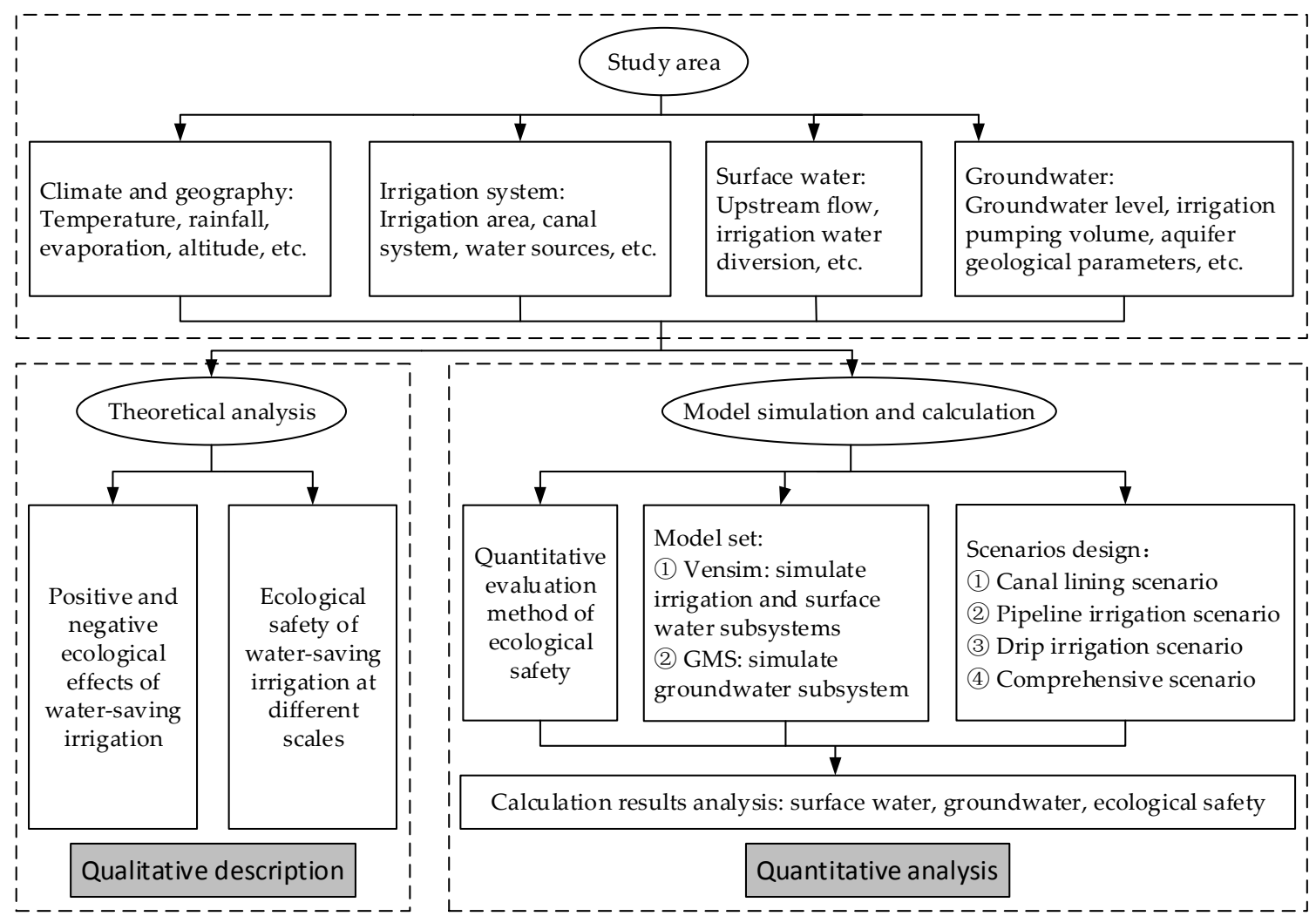

Figure 1. Flow chart of the methodology.

\subsection{Study Area}

The study area is Changma Irrigation District, which is located in the middle reaches of the Shule River Basin and at the western end of Gansu Province of China, as shown in Figure 2. It is the main agricultural development zone in the basin and is a large-scale self-flow irrigation district in the country. The total population is about 143,800 , the proportion of industry in the local economy is small, and water resources are mainly used for agricultural production. The industrial water demand is about 25.16 million $\mathrm{m}^{3}$, and the agricultural water demand is about 385 million $\mathrm{m}^{3}$. After the full implementation of the Comprehensive Development Project for Agricultural Irrigation and Resettlement of Hexi Corridor (Shule River) in Gansu Province, the development of regional water and soil resources had been carried out rapidly, the development of irrigated area in Changma Irrigation District is shown in Table 1.

Table 1. Development of irrigated area in Changma Irrigation District.

\begin{tabular}{cccccccc}
\hline Year & $\mathbf{1 9 4 9}$ & $\mathbf{1 9 6 5}$ & $\mathbf{1 9 8 3}$ & $\mathbf{1 9 9 5}$ & $\mathbf{2 0 0 4}$ & $\mathbf{2 0 0 7}$ & $\mathbf{2 0 1 7}$ \\
\hline Irrigated area (ha) & 13,300 & 15,667 & 22,667 & 28,400 & 30,667 & 43,427 & 46,454 \\
\hline
\end{tabular}

However, the large amount of agricultural water interception in the middle reaches of the Shule River Basin has led to a series of ecological environment deterioration problems in the downstream area, such as river cutoff, groundwater level decline, dryness of the tail lake and land desertification, the ecological environment has been changed significantly. Therefore, there is an urgent need for water saving. The Comprehensive Planning of the Rational Use and Ecological Protection of Dunhuang Water Resources was approved by the State Council of China in 2011, in which implementing water-saving irrigation to release more ecological flow to the downstream is an important way to restore downstream 
ecology. However, the large-scale implementation of water-saving irrigation will generate ecological risks. This study constructed an ecological safety assessment model for the irrigation district, after the calibration and validation based on measured data, the ecological safety of different scaled water-saving irrigation scenarios was evaluated.

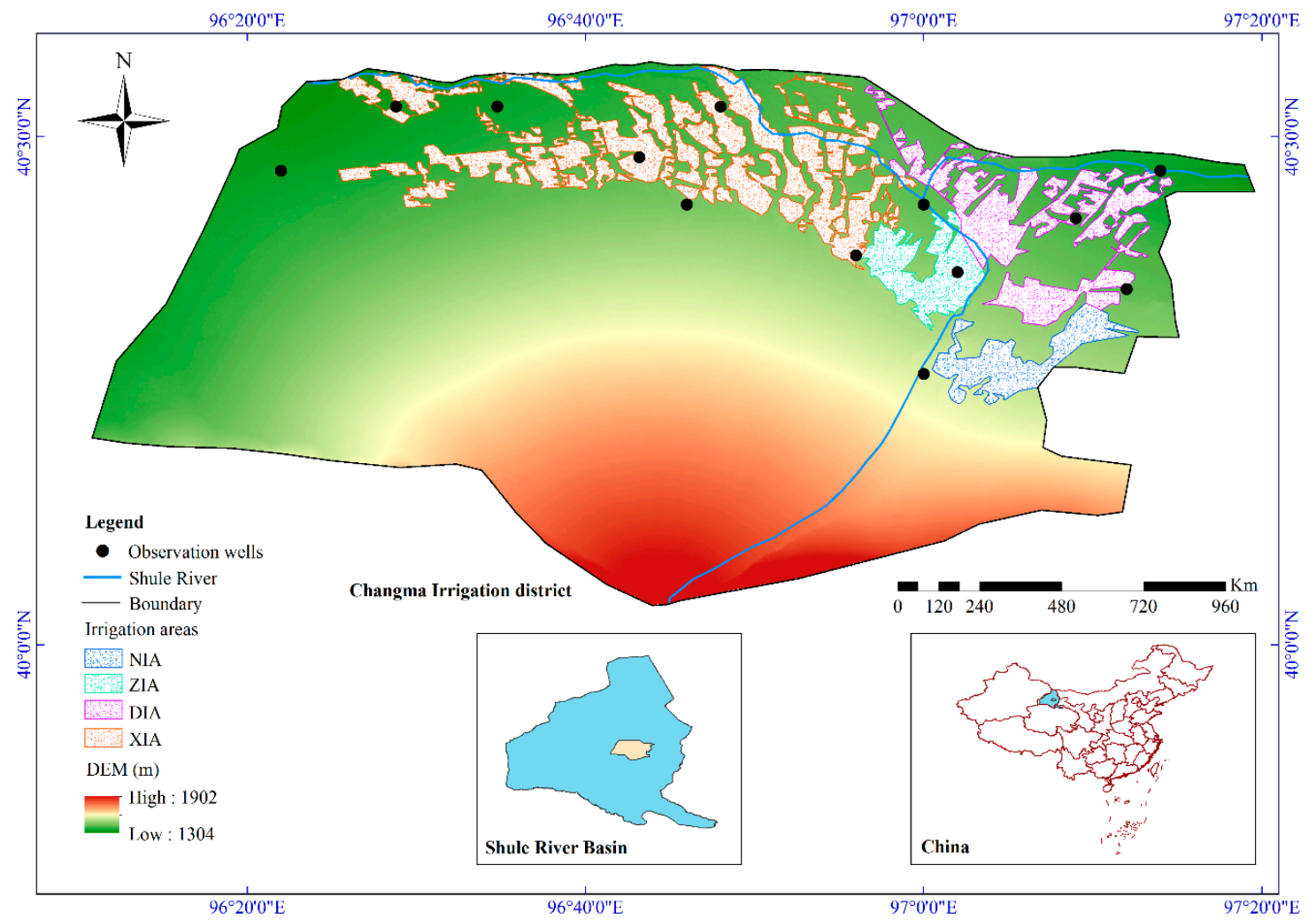

Figure 2. Geographical location, topography, and irrigation area of the study area.

The terrain of Changma Irrigation District is high in the south and low in the north with an altitude range of 1300-1885 m, the east-west span is about $85 \mathrm{~km}$, and the north-south span is about $55 \mathrm{~km}$. The climate is temperate continental and extremely arid climate, with short, hot summer and long, cold winter. The annual average temperature is $5.8-8.8^{\circ} \mathrm{C}$, the highest temperature is $36.7-45.1^{\circ} \mathrm{C}$, the lowest temperature is $-29.3--27.6^{\circ} \mathrm{C}$, the frost-free period is $135-146$ days, the sunshine is long (3265-3317 h), and the temperature difference between day and night is large $\left(15.6-17.3^{\circ} \mathrm{C}\right)$. The range of precipitation is $47.7-61.8 \mathrm{~mm}$ and that of evaporation is $2484-3042 \mathrm{~mm}$. The total irrigated area of the Changma Irrigation District is 46,453 hectares. There are three kinds of irrigation water sources, which are river water, groundwater and spring water, accounting for $85.49 \%, 13.83 \%$ and $0.67 \%$ respectively. The salinity of surface water is less than $0.5 \mathrm{~g} / \mathrm{L}$, and that of groundwater is $1.0-2.5 \mathrm{~g} / \mathrm{L}$. The main irrigation method is border irrigation, and the main water-saving irrigation measure is channel lining project. The development of the water utilization coefficient of canal system is shown in Table 2. The Changma Irrigation District can be divided into the Nangan Irrigation Area (NIA), Zongyizhigan Irrigation Area (ZIA), Dongbeigan Irrigation Area (DIA), and Xigan Irrigation Area (XIA) according to main canals. The water of the Shule River is used in three aspects: irrigation, external water transfer, and ecological water discharge. Among them, the three aspects account for $28 \%, 20 \%$, and $52 \%$ respectively.

Table 2. Development of canal water utilization coefficient in Changma Irrigation District.

\begin{tabular}{cccccccc}
\hline Year & $\mathbf{1 9 5 8}$ & $\mathbf{1 9 7 0}$ & $\mathbf{1 9 8 0}$ & $\mathbf{1 9 9 0}$ & $\mathbf{2 0 0 0}$ & $\mathbf{2 0 1 0}$ & $\mathbf{2 0 1 7}$ \\
\hline Canal water utilization coefficient & 0.18 & 0.24 & 0.27 & 0.33 & 0.37 & 0.51 & 0.69 \\
\hline
\end{tabular}




\subsection{Quantitative Assessment of Ecological Safety for Large-Scale Water-Saving Irrigation}

In order to explore the impacts of different large-scale water-saving irrigation scenarios on the ecological safety of irrigation district and quantitatively evaluate them, it is necessary to establish an ecological safety assessment model for the irrigation district. This study used the Vensim model to construct the irrigation subsystem and surface water subsystem in the irrigation district. Different water-saving irrigation scenarios can be described by setting different irrigation areas, canal water utilization coefficients, and field percolation coefficients. The surface water subsystem was described by inputting the amount of water from the upstream of the river, irrigation water diversion, and the leakage coefficient of the river. The influence of different water-saving irrigation scenarios on the groundwater level was described based on the GMS model to construct the groundwater subsystem, and the model was calibrated and validated by using the measured groundwater level in the irrigation district.

In arid inland river basin, water resources are scarce and evaporation is strong, groundwater level is the most important indicator of ecological safety. The critical groundwater depths selected for analysis are $2 \mathrm{~m}, 5 \mathrm{~m}$ and $7 \mathrm{~m}$, respectively. Among them, $2 \mathrm{~m}$ is the warning groundwater depth of phreatic evaporation causing strong salt return, $5 \mathrm{~m}$ is the ultimate groundwater depth for the survival of the natural farmland shelterbelt in the arid inland river basin in Northwest China, and $7 \mathrm{~m}$ is the ultimate groundwater depth for the survival of the main natural vegetation in the study area. The artificial oasis was established by intercepting the water resources originally belonging to the natural oasis, in order to restore the natural oasis, it is reasonable to sacrifice some of the benefits of the artificial oasis under current condition. However, in order to control the impact of large-scale water-saving irrigation on local ecological safety, it is necessary to set a warning scale threshold. In this study, the warning scale of large-scale water-saving irrigation is set as the scale when the area of local ecologically suitable groundwater depth decreases by no more than $20 \%$. In order to control the secondary salinization of the soil and protect the natural ecological vegetation, the ecologically suitable groundwater depth in arid inland river basin is set at $2-5 \mathrm{~m}$.

Since the ecological safety of large-scale water-saving irrigation involves multiple subsystems, this study used a comprehensive evaluation method for evaluation. Firstly, the ecological safety status of each subsystem was calculated, and then integrated into the ecological safety of the irrigation district. The ecological safety index of the irrigation district (ESI) was defined to characterize the ecological safety of the irrigation district under the condition of large-scale water-saving irrigation.

$$
\mathrm{ESI}=\frac{1}{4} \times \sum_{\mathrm{i}=1}^{4} \mathrm{SESI}_{\mathrm{i}}
$$

where $\mathrm{SESI}_{\mathrm{i}}$ is the ecological safety index of each subsystem. The ecological safety of the soil subsystem $\left(\mathrm{SESI}_{1}\right)$ is calculated by the salinization-prone area to explore the effect of water-saving irrigation on the salinization of the irrigation district. It is assumed that $\mathrm{SESI}_{1}$ is 0 under the current condition, and is 1 when the salinization-prone area is reduced by $80 \%$.

$$
\mathrm{SESI}_{1}=\left(\left(\mathrm{S}_{\mathrm{s} 0}-\mathrm{S}_{\mathrm{s}}\right) / \mathrm{S}_{\mathrm{s} 0}\right) / 0.8
$$

where $S_{\mathrm{s} 0}$ and $S_{\mathrm{s}}$ are the salinization-prone areas under current condition and a water-saving irrigation scenario $\left(\mathrm{km}^{2}\right)$. The ecological safety of the surface water subsystem $\left(\mathrm{SESI}_{2}\right)$ can indicate the impact of water-saving irrigation on the amount of downstream water resources.

$$
\mathrm{SESI}_{2}=\mathrm{WDD} / \mathrm{WI}_{\mathrm{gmc}}
$$

where $\mathrm{WDD}$ is the water volume delivered to downstream $\left(\mathrm{m}^{3}\right) ; \mathrm{WI}_{\mathrm{gmc}}$ is the irrigation water intake at the head of general main canal $\left(\mathrm{m}^{3}\right)$. The ecological safety of the groundwater subsystem $\left(\mathrm{SESI}_{3}\right)$ is calculated by the reduction rate of area with ecologically suitable groundwater depth to explore the impact of large-scale water-saving irrigation on the groundwater depth. It is assumed that $\mathrm{SESI}_{3}$ is 
1 under current condition, and is 0 when the area of the ecologically suitable groundwater depth is reduced to $20 \%$.

$$
\mathrm{SESI}_{3}=\left(20 \%-\left(\mathrm{S}_{\mathrm{es} 0}-\mathrm{S}_{\mathrm{es}}\right) \times 100 / \mathrm{S}_{\mathrm{es} 0}\right) / 20 \%
$$

where $S_{\text {es } 0}$ and $S_{\text {es }}$ are the areas with ecologically suitable groundwater depth (2-5 m) under current condition and a water saving irrigation scenario $\left(\mathrm{km}^{2}\right)$. The ecological safety index of the biology subsystem $\left(\mathrm{SESI}_{4}\right)$ include the protection degree of the farmland shelterbelt and that of natural vegetation, which can represent the impact of large-scale water-saving irrigation on farmland shelterbelt and natural vegetation, respectively. The formulas for the calculation are as follows.

$$
\begin{gathered}
\mathrm{SESI}_{4}=(\mathrm{FSS}+\mathrm{NVS}) / 2 \\
\mathrm{FSS}=(\mathrm{IFSS}+(1-\mathrm{CFSD})+\mathrm{NFSS}) / 3 \\
\mathrm{NVS}=(\mathrm{RNVS}+\mathrm{GNVS}) / 2
\end{gathered}
$$

where FSS and NVS are the ecological safety of farmland shelterbelt and natural vegetation; IFSS is the ecological safety of irrigated farmland shelterbelt; CFSD is the degradation degree of farmland shelterbelt along the canal; NFSS is the ecological safety of the natural farmland shelterbelt; RNVS is the ecological safety of valley vegetation that relies on the lateral leakage of river water to survive; GNVS is the ecological safety of natural vegetation that depends on groundwater for survival.

$$
\begin{gathered}
\text { IFSS }=\mathrm{S}_{\mathrm{d}} / \mathrm{S} \\
\text { CFSD }=\left(\mathrm{CS}_{\mathrm{c}}-\mathrm{CS}\right) \times 100 / \mathrm{CS}_{\mathrm{t}} \\
\mathrm{NFSS}=\left(20 \%-\left(\mathrm{S}_{\mathrm{fs} 0}-\mathrm{S}_{\mathrm{fs}}\right) \times 100 / \mathrm{S}_{\mathrm{af} 0}\right) / 20 \% \\
\text { RNVS }=(\mathrm{WDW}-\mathrm{WDC}) / \mathrm{WDC} \\
\text { GNVS }=\left(20 \%-\left(\mathrm{S}_{\mathrm{nv} 0}-\mathrm{S}_{\mathrm{nv}}\right) \times 100 / \mathrm{S}_{\mathrm{nv} 0}\right) / 20 \%
\end{gathered}
$$

where $S_{d}$ is the area of drip irrigation $\left(\mathrm{km}^{2}\right) ; \mathrm{S}$ is the irrigation area $\left(\mathrm{km}^{2}\right) ; \mathrm{CS}_{\mathrm{c}}$ and $\mathrm{CS}$ are the water volumes of canal seepage under current condition and a water-saving irrigation scenario $\left(\mathrm{m}^{3}\right)$; $\mathrm{S}_{\mathrm{fs} 0}$ and $\mathrm{S}_{\mathrm{fs}}$ are the areas with survival groundwater depth for farmland shelterbelt $(0-5 \mathrm{~m})$ under current condition and a water-saving irrigation scenario $\left(\mathrm{km}^{2}\right) . S_{\mathrm{nv} 0}$ and $S_{\mathrm{nv}}$ are the areas with survival groundwater depth for natural vegetation $(0-7 \mathrm{~m})$ under current condition and a water-saving irrigation scenario $\left(\mathrm{km}^{2}\right)$.

\subsection{Simulation Models}

The irrigation subsystem and surface water subsystem of the ecological safety assessment model of the Changma Irrigation District were constructed using the Vensim model, while the groundwater subsystem was constructed using the GMS model. The schematic structure of the applied model is shown in Figure 3.

The irrigation subsystem and surface water subsystem of the Changma Irrigation District are shown in Figure 4, they can provide important source and sink values for the groundwater model, such as the groundwater pumping volume, irrigation seepage replenishment and river leakage replenishment.

$$
\begin{gathered}
\mathrm{AIA}_{\mathrm{gw}}=\mathrm{IA}_{\mathrm{gw}} / \mathrm{S} \\
\mathrm{IA}_{\mathrm{gw}}=\mathrm{IA}_{\mathrm{sw}} \times \mathrm{RWC} \\
\mathrm{IA}_{\mathrm{sw}}=\mathrm{WI}_{\mathrm{mc}} \times \mathrm{WUC}_{\mathrm{mc}} \times \mathrm{WUC}_{\mathrm{bc}} \times \mathrm{WUC}_{\mathrm{lc}}
\end{gathered}
$$

where $\mathrm{AIA}_{\mathrm{gw}}$ is the average groundwater pumping depth per unit area $(\mathrm{m})$; $\mathrm{IA}_{\mathrm{gw}}$ is the total groundwater pumping volume $\left(\mathrm{m}^{3}\right) ; \mathrm{S}$ is the irrigation area $\left(\mathrm{m}^{2}\right) ; \mathrm{IA}_{\mathrm{sw}}$ is the net irrigation volume of surface water $\left(\mathrm{m}^{3}\right)$; RWC is the area ratio of well irrigation and canal irrigation; $\mathrm{WI}_{\mathrm{mc}}$ is the irrigation 
water intake at the head of main canal $\left(\mathrm{m}^{3}\right)$; and $\mathrm{WUC}_{\mathrm{mc}}, \mathrm{WUC}_{\mathrm{bc}}, \mathrm{WUC}_{\mathrm{lc}}$ are the water use coefficients of main canal, branch canal and lower-level canals.

$$
\begin{aligned}
& \mathrm{AR}_{\mathrm{i}}=\mathrm{R}_{\mathrm{i}} / \mathrm{S} \\
& \mathrm{R}_{\mathrm{i}}=\mathrm{R}_{\mathrm{cs}}+\mathrm{R}_{\mathrm{fp}} \\
& \mathrm{R}_{\mathrm{cs}}=\left(\mathrm{WI}_{\mathrm{mc}}-\mathrm{IA}_{\mathrm{sw}}\right) \times(1-\beta) \\
& \mathrm{R}_{\mathrm{cs} \_} \mathrm{GMC}=\mathrm{WI}_{\mathrm{gmc}} \times\left(1-\mathrm{WUC}_{\mathrm{gmc}}\right) \times(1-\beta) \\
& \mathrm{R}_{\mathrm{fp}}=\mathrm{IA} \times \mathrm{RC}_{\mathrm{fp}} \\
& \mathrm{IA}=\mathrm{IA}_{\mathrm{sw}}+\mathrm{IA}_{\mathrm{gw}}
\end{aligned}
$$

where $A R_{i}$ is the average irrigation seepage replenishment depth per unit area $(m) ; R_{i}$ is the irrigation seepage replenishment $\left(\mathrm{m}^{3}\right) ; R_{\mathrm{cs}}$ is the seepage replenishment from irrigation canals $\left(\mathrm{m}^{3}\right) ; \mathrm{R}_{\mathrm{fp}}$ is the percolation replenishment from irrigation in the field $\left(\mathrm{m}^{3}\right) ; \beta$ is the loss coefficient of evaporation and water storage in aeration zone; $\mathrm{R}_{\mathrm{cs}} \mathrm{GMC}$ is the seepage replenishment from the general main canal $\left(\mathrm{m}^{3}\right)$; $\mathrm{WUC}_{\mathrm{gmc}}$ is the water use coefficient of general main canal; IA is the total net irrigation volume in the field $\left(\mathrm{m}^{3}\right)$; and $\mathrm{RC}_{\mathrm{fp}}$ is the percolation replenishment coefficient in field.

$$
\begin{aligned}
\mathrm{R}_{\mathrm{rl}} & =\mathrm{RD} \times \mathrm{RC}_{\mathrm{rl}} \\
\mathrm{RD} & =\mathrm{UF}-\mathrm{WI}_{\mathrm{gmc}}
\end{aligned}
$$

where $\mathrm{R}_{\mathrm{rl}}$ is the river leakage replenishment $\left(\mathrm{m}^{3}\right)$; $\mathrm{RD}$ is the river discharge at the head of general main canal $\left(\mathrm{m}^{3}\right) ; \mathrm{RC}_{\mathrm{rl}}$ is the river leakage coefficient; UF is the water amount coming from the upper reaches of the river $\left(\mathrm{m}^{3}\right)$.

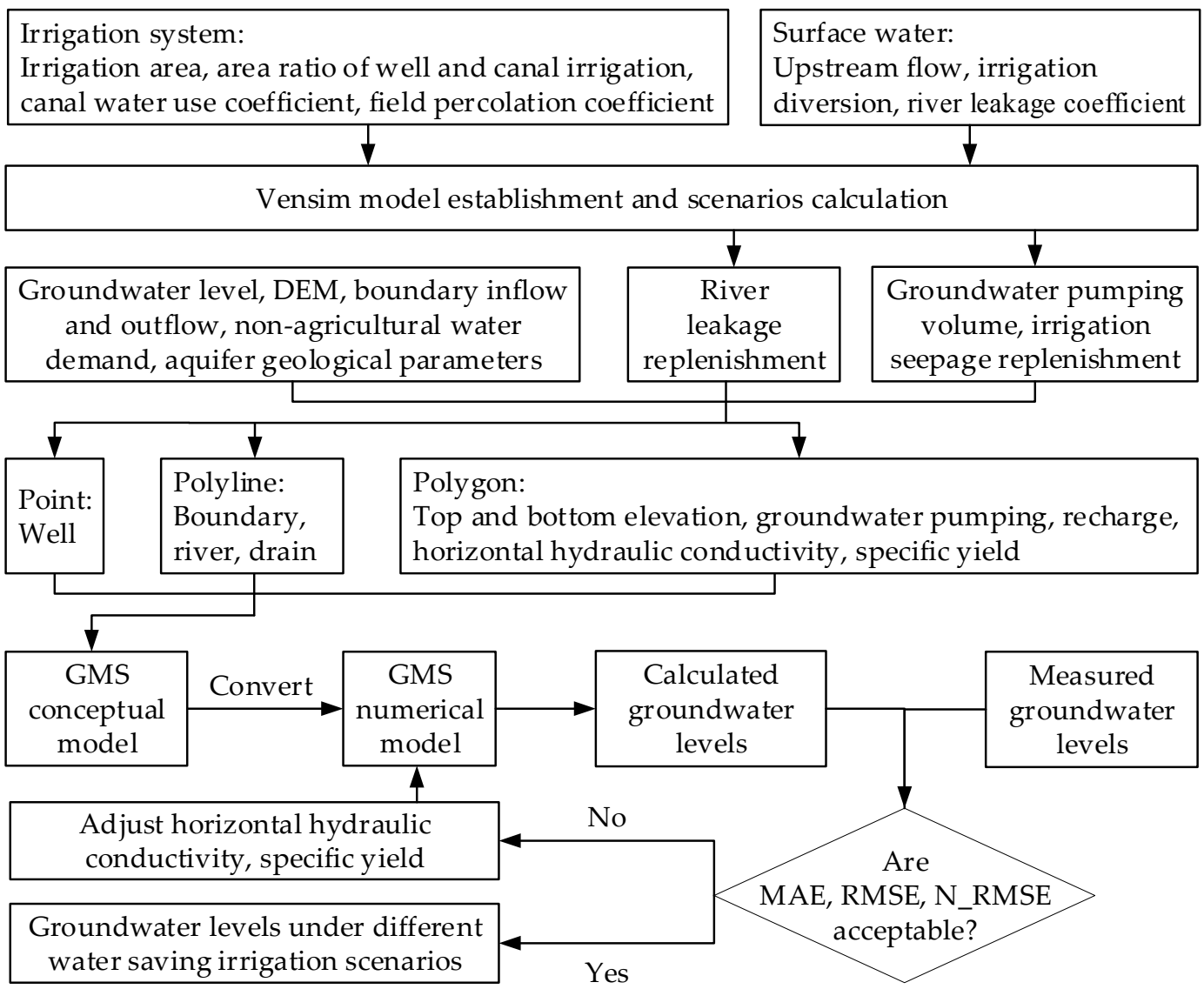

Figure 3. Schematic structure of the applied model. 

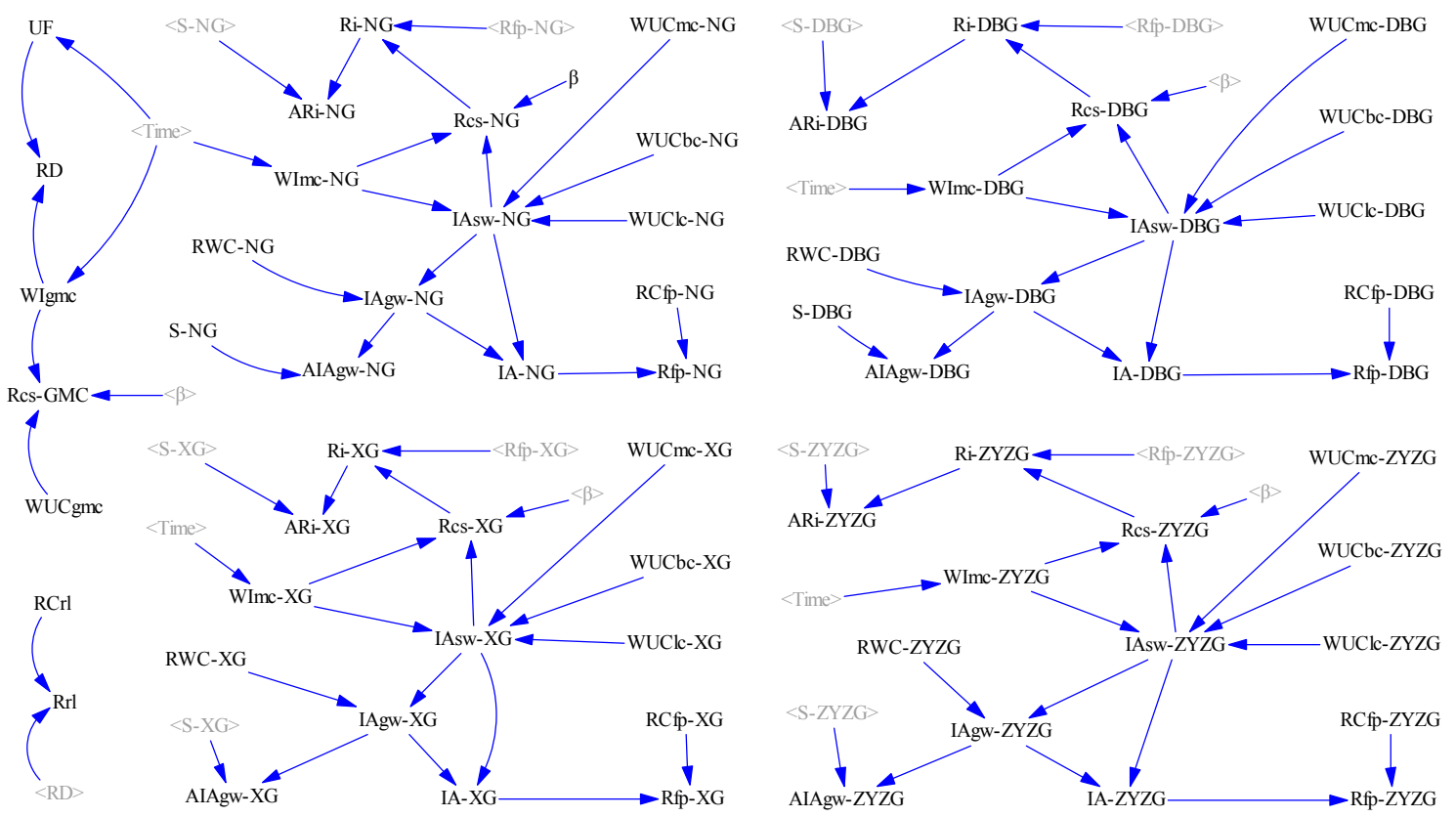

Figure 4. Structure diagram of irrigation and surface water subsystems in the Changma Irrigation District.

In this GMS model, the MODFLOW module developed by the US Geological Survey was used to simulate the groundwater system in the irrigation district. The model's calculation range is about $60 \mathrm{~km}$ from north to south and $100 \mathrm{~km}$ from east to west, and the calculation area is $3750 \mathrm{~km}^{2}$ which is divided into 4217 grids. There are massive water-bearing sedimentary rocks and intrusive rocks on the eastern boundary, which can be set as water-blocking boundary. The northeast boundary is connected to the aquifer of the Huahai Basin, which can be set as groundwater outflow boundary. Judging from the groundwater contour, the middle section of the western boundary is the outflow boundary of the groundwater. Since the water level changes little, it can be set as specified head boundary. The water level affected by the Shuangta Reservoir in the northwest boundary is relatively stable, so the boundary can also be set as specified head boundary. The very large compressive fault in the southern boundary prevents large-scale replenishment of underflow to the study area, underflow only exists at the Changmaxia exit of the Shule River, which can be set as groundwater inflow boundary. The northern boundary is close to the north side of the Shule River, where the groundwater is undeveloped and can be set as water-blocking boundary. The central and southern parts of the Changma Basin are the Gobi Desert, where the groundwater depths are deep. The Changma Irrigation District is located in the fine soil plain in the north. Irrigation canal leakage and field percolation are important vertical replenishment sources of groundwater. Since the groundwater depth is relatively shallow, the phreatic evaporation is intense. There are frequent exchanges of water in soil water system, river water system and groundwater system. The general main canal in the Southern Gobi Desert area was simulated using the River module of MODFLOW, and the spring water discharge and irrigation drainage in the northern fine soil plain were simulated by the Drain module. Since the irrigation canals and groundwater extraction wells are dense, the canal leakage and groundwater extraction in the irrigation areas were generalized into plane flux. They were both set as Recharge type in the model, and partitioned according to different irrigation areas. The average annual precipitation is $66.7 \mathrm{~mm}$, while the evaporation intensity is strong, so the groundwater replenishment by precipitation can be negligible [32,33]. The phreatic evaporation was calculated by using the ETS package in the model.

Based on the groundwater level data from 13 observation wells which are shown in Figure 2, the model was calibrated and validated by combining the trial-and-error method and PEST optimization adjustment. The parameters calibrated are the horizontal hydraulic conductivity and specific yield, 
in which the initial values of the horizontal hydraulic conductivity in study area vary from 5.2 to $162 \mathrm{~m} / \mathrm{d}$, and that of the specific yield vary from 0.06 to 0.35 . The calibration period was from 1 January 2017 to 31 December 2017, while the validation period was from 1 January 2016 to 31 December 2016, and they were divided into twelve stress periods. To quantitatively evaluate the fitting effect of the model on the groundwater level, the mean absolute error (MAE), the root mean square error (RMSE) and the normalized root mean square error (N_RMSE) between the simulated and measured values were calculated.

$$
\begin{gathered}
\text { MAE }=\frac{1}{n} \sum_{i=1}^{n}\left|h_{\text {isim }}-h_{\text {iobs }}\right| \\
\text { RMSE }=\sqrt{\frac{1}{n} \sum_{i=1}^{n}\left(h_{\text {isim }}-h_{\text {iobs }}\right)^{2}} \\
\text { N_RMSE }=\frac{\text { RMSE }}{\left(\mathrm{h}_{\text {obs }}\right)_{\text {max }}-\left(\mathrm{h}_{\text {obs }}\right)_{\text {min }}}
\end{gathered}
$$

where $n$ is the total number of fitted data; $h_{\text {isim }}$ and $h_{\text {iobs }}$ are the simulated and measured values of the groundwater level $(\mathrm{m}) ;\left(\mathrm{h}_{\mathrm{obs}}\right)_{\max }$ and $\left(\mathrm{h}_{\mathrm{obs}}\right)_{\min }$ are the maximum and minimum measured values of the groundwater level in the fitted data $(\mathrm{m})$.

The statistical indicators for the simulation effect of groundwater level in the study area are shown in Table 3. The MAE, RMSE, and NRMSE between the measured and simulated values of groundwater level were $0.67 \mathrm{~m}, 0.95 \mathrm{~m}$, and $0.56 \%$ in the calibration stage, while those were $0.75 \mathrm{~m}, 1.16 \mathrm{~m}$, and $0.69 \%$ in the validation stage.

Table 3. Evaluation index of groundwater level simulation effect.

\begin{tabular}{cccc}
\hline Time Period & MAE $(m)$ & RMSE(m) & NRMSE \\
\hline Calibration stage & 0.67 & 0.95 & $0.56 \%$ \\
Validation stage & 0.75 & 1.16 & $0.69 \%$ \\
\hline
\end{tabular}

The distribution of the absolute errors of groundwater level in all observation wells during the simulation period is shown in Table 4 . The number of simulated points with a simulated error less than $1.2 \mathrm{~m}$ accounted for $87.82 \%$ in the calibration stage, while that in the validation stage was $86.54 \%$. Therefore, the simulation results of the groundwater level were generally satisfactory, the model can be used for the simulation analysis of the hydrological cycle in the irrigation district.

Table 4. Number and proportion of absolute errors of simulated and measured groundwater level.

\begin{tabular}{ccccccc}
\hline Time Period & Absolute Error & {$[\mathbf{0 , 0 . 2 )}$} & {$[\mathbf{0 . 2 , 0 . 5 )}$} & {$[\mathbf{0 . 5 , 1 . 0 )}$} & {$[\mathbf{1 . 0 , 1 . 2 )}$} & {$[\mathbf{1 1 . 2 , + \infty )}$} \\
\hline $\begin{array}{c}\text { Calibration } \\
\text { stage }\end{array}$ & Number & 43 & 33 & 48 & 13 & 19 \\
\hline Percentage (\%) & $27.56 \%$ & $21.15 \%$ & $30.77 \%$ & $8.33 \%$ & $12.18 \%$ \\
\hline Validation & Number & 31 & 34 & 58 & 12 & 21 \\
stage & Percentage (\%) & $19.87 \%$ & $21.79 \%$ & $37.18 \%$ & $7.69 \%$ & $13.46 \%$ \\
\hline
\end{tabular}

The comparisons between the measured and simulated values of the groundwater level during the calibration and validation stages in study area are shown in Figure 5. The simulated points of groundwater level during the simulation period were all distributed near the 1:1 line. Therefore, the simulation results of the groundwater level were generally satisfactory, the model can be used for the simulation analysis of the hydrological cycle in the irrigation district. However, the current groundwater observation wells are mainly distributed in the irrigation district, which is located in the fine soil plain in the northern part of the study area. The groundwater data in the central and 
southern Gobi Desert are relatively scarce. In the future, more data should be added to further improve the model.
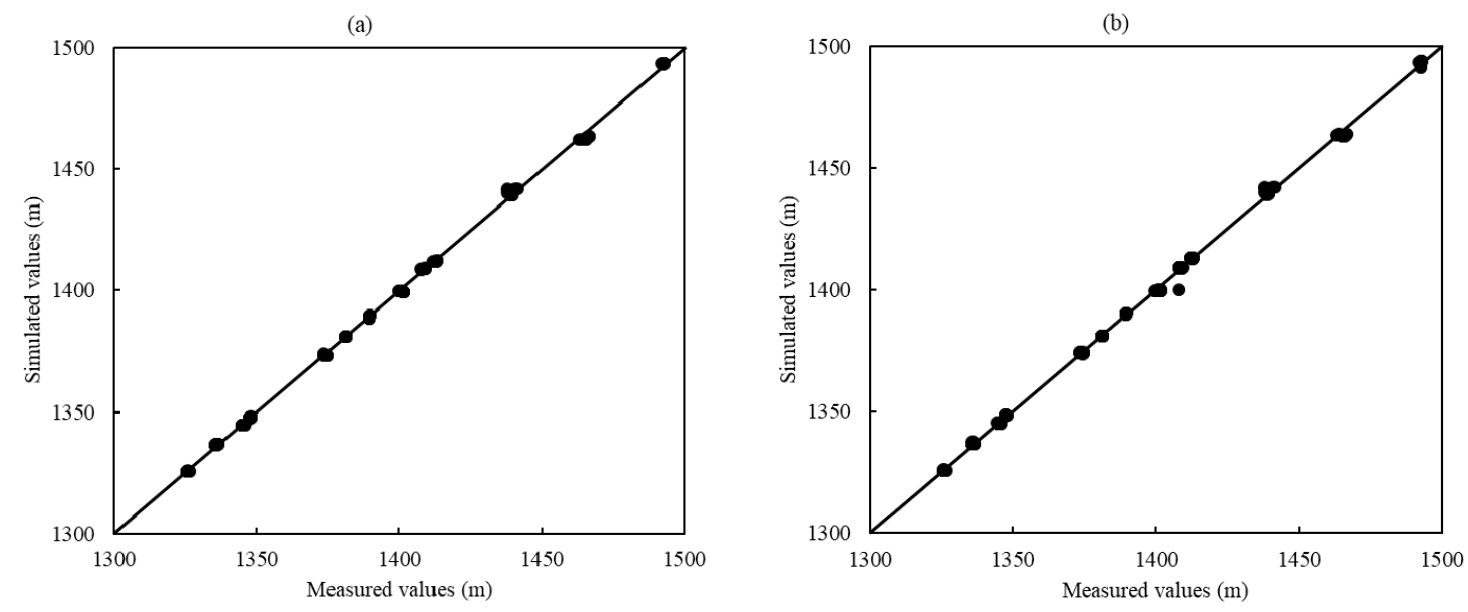

Figure 5. Comparisons of measured and simulated groundwater level during the (a) calibration stage and (b) validation stage in the Changma Irrigation District.

\subsection{Scenarios of Scaled Water-Saving Irrigation}

Different large-scale water-saving irrigation scenarios based on the current situation were set up to explore and evaluate their effects on the ecological safety of irrigation district, in which the total irrigated area remained unchanged.

Four typical scenarios of large-scale water-saving irrigation in Changma Irrigation District are shown in Table 5. Scenario 1 (S-1) is a canal lining scenario in which the canal water utilization coefficients were increased to 0.95 to explore the impact of large-scale canal lining on the ecological safety of the irrigation district. Scenario 2 (S-2) was a pipeline irrigation scenario that increased the proportion of pipeline irrigation area in each irrigation area to $50 \%$ while the canal water utilization coefficients of river irrigation area maintained the current level, which was used to explore the impact of large-scale pipeline water delivery technology on the ecological safety of irrigation district. The Nangan Irrigation Area (NIA) was excluded because the groundwater depth is relatively deep, so large-area pumping irrigation is not economical. The pipeline irrigation scenario was also a well irrigation scenario, it was assumed that the well irrigation used pipelines for water transportation, while river water irrigation used canals for transportation. Scenario 3 (S-3) was a drip irrigation scenario. On the basis of Scenario 2, the traditional irrigation method on pipeline irrigation area was replaced by drip irrigation to explore the impact of large-scale water-saving irrigation technology in the field on the ecological safety of irrigation district. Scenario 4 (S-4) was a comprehensive scenario, in which the canal system upgrade was carried out on the basis of the Scenario 3. It was used to explore the impact of full implementation of large-scale water-saving irrigation technology on the ecological safety of irrigation district.

Table 5. Typical large-scale water-saving irrigation scenarios in Changma Irrigation District.

\begin{tabular}{ccccc}
\hline Number & $\begin{array}{c}\text { Total Irrigated } \\
\text { Area (ha) }\end{array}$ & $\begin{array}{c}\text { Canal Water Use } \\
\text { Coefficient }\end{array}$ & $\begin{array}{c}\text { Pipe Irrigation } \\
\text { Area (ha) }\end{array}$ & $\begin{array}{c}\text { Drip Irrigation } \\
\text { Area (ha) }\end{array}$ \\
\hline S-1 & 46,453 & 0.95 & 7767 & 0 \\
S-2 & 46,453 & Current situation & 20,808 & 0 \\
S-3 & 46,453 & Current situation & 20,808 & 20,808 \\
S-4 & 46,453 & 0.95 & 20,808 & 20,808 \\
\hline
\end{tabular}




\section{Results}

\subsection{Ecological Benefits and Risks of Water-Saving Irrigation}

Water-saving irrigation will generate a series of positive and negative effects on farmland ecosystems. It can improve the ecological security of farmland and natural environment, which will also produce some ecological risks. The main ecological safety benefits and risks of water-saving irrigation are shown in Table 6.

Table 6. Main ecological benefits and risks of water-saving irrigation.

\begin{tabular}{|c|c|c|}
\hline Subsystem & Ecological Benefits & Ecological Risks \\
\hline $\begin{array}{c}\text { Soil } \\
\text { subsystem }\end{array}$ & $\begin{array}{l}\text { (i) Reduce runoff, soil compaction, and erosion } \\
\text { caused by flooding. } \\
\text { (ii) Lower the groundwater level in the surface } \\
\text { water irrigation district, reducing the soil salt } \\
\text { return from groundwater. } \\
\text { (iii) Reduce the amount of fertilization and } \\
\text { mitigate soil pollution. }\end{array}$ & $\begin{array}{l}\text { (i) Affect soil leaching and desalination } \\
\text { process, triggering secondary salinization. } \\
\text { (ii) Make surface soil dry, triggering the risk } \\
\text { of soil desiccation and desertification. }\end{array}$ \\
\hline $\begin{array}{l}\text { Surface water } \\
\text { subsystem }\end{array}$ & $\begin{array}{l}\text { (i) Reduce irrigation water diversion from river, } \\
\text { returning more river flow to improve the } \\
\text { ecological environment of river. } \\
\text { (ii) Reduce the amount of irrigation drainage, } \\
\text { mitigating the impact of agricultural non-point } \\
\text { source pollution on surface water quality. }\end{array}$ & $\begin{array}{l}\text { (i) Reduce irrigation drainage, causing } \\
\text { shrinkage or degradation of lakes or } \\
\text { wetlands. }\end{array}$ \\
\hline $\begin{array}{l}\text { Groundwater } \\
\text { subsystem }\end{array}$ & $\begin{array}{l}\text { (i) Reduce irrigation quota in well irrigation } \\
\text { districts, inhibiting groundwater } \\
\text { over-exploitation. } \\
\text { (ii) Reduce amount of percolation in the field, } \\
\text { mitigating the impact of agricultural non-point } \\
\text { source pollution on groundwater quality. }\end{array}$ & $\begin{array}{l}\text { (i) Reduce irrigation leakage replenishment, } \\
\text { resulting in a drop of groundwater level in } \\
\text { the irrigation district. }\end{array}$ \\
\hline $\begin{array}{c}\text { Biology } \\
\text { subsystem }\end{array}$ & $\begin{array}{l}\text { (i) Reduce irrigation water diversion from the } \\
\text { river, improving river valley vegetation and the } \\
\text { downstream ecosystem. } \\
\text { (ii) Reduce irrigation pumping, increasing } \\
\text { natural vegetation coverage. }\end{array}$ & $\begin{array}{l}\text { (i) Reduce or eliminate canal leakage, } \\
\text { resulting in degradation of farmland } \\
\text { shelterbelt along the canal. } \\
\text { (ii) Reduce the groundwater level, affecting } \\
\text { the living environment of natural vegetation } \\
\text { that depends on groundwater. } \\
\text { (iii) Cause dryness in the field, incurring } \\
\text { plagues of locusts. } \\
\text { (iv) Produce high humidity in the field, } \\
\text { causing plagues of wet pests, and diseases. }\end{array}$ \\
\hline
\end{tabular}

For the soil subsystem, water-saving irrigation can reduce the wet area and runoff in the field, alleviate soil compaction and soil erosion problems caused by flood irrigation, which are conducive to soil and water conservation in farmland. Moreover, it can lower the excessively high groundwater level in the surface water irrigation district, alleviate soil salinization caused by strong phreatic evaporation. In addition, precise fertilization under water-saving irrigation can reduce the fertilizer dosage and improve fertilizer utilization, then the residual fertilizer pollution of the soil by "comprehensive" fertilization under the traditional irrigation mode can be reduced. However, the sharp reduction of field percolation caused by water-saving irrigation will affect the soil leaching and desalination process, triggering secondary salinization of the soil. In addition, water-saving irrigation technology, such as subsurface drip irrigation, only wets the root zone of the crop, and makes large areas of the surface soil dry, which may trigger the risks of soil desiccation and desertification.

For the surface water subsystem, implementation of water-saving irrigation technology can reduce the amount of irrigation water diversion from river, then return more water to the river to improve its ecological environment. Moreover, it can reduce the amount of irrigation drainage, then mitigate the 
pollution of surface water caused by agricultural non-point source pollution. However, water-saving irrigation will greatly reduce the amount of irrigation drainage, resulting in the risks of shrinkage or degradation of some lakes or wetlands which are dependent on irrigation return water.

For the groundwater subsystem, water-saving irrigation can reduce the irrigation quota in well irrigation areas, then inhibit groundwater over-exploitation. In addition, it can reduce the irrigation percolation in the field, then mitigate the pollution of groundwater caused by agricultural non-point source pollution. However, the application of canal lining, pipeline water delivery, and field water-saving irrigation technology will reduce the amount of leakage in the canal and percolation in the field, which may lead to a significant decline in groundwater level in the irrigation district and affect the regional water cycle process.

For the biological subsystem, water-saving irrigation can increase river runoff, then improve the vegetation condition of river valley and the downstream ecosystem. In addition, it can reduce the amount of groundwater pumping in well irrigation district, then raise the groundwater level and improve the coverage of natural vegetation. However, the canal lining and pipeline water delivery will reduce or eliminate the canal leakage, then cause the degradation of farmland shelterbelt along the canal. In addition, the sharp decrease of groundwater replenishment by irrigation leakage will cause the groundwater level to drop, which will change the living environment and ecological pattern of natural vegetation that depends on groundwater in the arid region. Moreover, subsurface drip irrigation makes the field microclimate dry, which may incur plagues of locusts, while sprinkler irrigation produces high humidity in the field which may cause plagues of wet pests and diseases.

\subsection{Ecological Safety Concernings of Water-Saving Irrigation at Different Scales}

The ecological effects of water-saving irrigation at different scales are shown in Table 7. For the plant scale, due to the less salt brought by irrigation, the soil salt content under water-saving irrigation condition is lower. In addition, drip irrigation can create a root zone environment with low salinity. Plant-scale water-saving irrigation has little effects on surface water and groundwater. Water-saving irrigation is characterized by a small single irrigation volume but high frequency, which can better meet the water requirement of crops, so it can promote plant growth and development. For the field scale, water-saving irrigation has a poor salt leaching capacity due to the small amount of deep leakage, which will increase the soil salinity in the field. As for the effects on water environment, field-scale water-saving irrigation still has little effects on surface water and groundwater. However, it can increase the leaf area index of crops in the field because of the ability to promote plant growth and development. For irrigation district scale, traditional irrigation districts often have high groundwater levels due to large irrigation quotas, phreatic evaporation brings a lot of salt into the soil, so the drainage pressure in irrigation districts is relatively high. However, scaled water-saving irrigation can significantly reduce the amount of irrigation leakage, as a result, the saline soil areas of the irrigation districts will decline. As for the effects on water environment, the implementation of large-scale water-saving irrigation will lower the groundwater level in the irrigation district, but can increase the ecological flow of the river. When it comes to the biological effects, the number of farmland shelterbelt along the canal will be reduced by canal lining and pipeline water delivery. Natural farmland shelterbelt and natural vegetation will deteriorate by the reduced groundwater table in the irrigation district. The area of irrigated farmland shelterbelt will be increased under the condition of water-saving irrigation. River valley vegetation in the irrigation district will be improved by increased river ecological flow. For the watershed scale, water-saving irrigation can reduce the saline soil area of the oasis by lowering the groundwater level. In terms of the effects on water environment, although large-scale water-saving irrigation will cause the groundwater level in local irrigation district to drop, it can increase river ecological flow and raise the downstream groundwater level, and then alleviate the problems such as the river cut-off and drying up of terminal lake. Correspondingly, in terms of biological effects, water-saving irrigation will cause the degradation of local natural vegetation to a certain extent, but it 
will improve the living environment of natural vegetation in the downstream region and increase the coverage of river valley vegetation.

Table 7. Ecological effects of water-saving irrigation at different scales.

\begin{tabular}{clcl}
\hline Scale & \multicolumn{1}{c}{ Soil Effects } & \multicolumn{1}{c}{ Water Effects } & \multicolumn{1}{c}{ Biological Effects } \\
\hline Plant & $\begin{array}{l}\text { (i) Reduce } \\
\text { salt content }\end{array}$ & \multicolumn{1}{c}{ Not obvious } & (i) Promote plant growth and development \\
\hline Field & $\begin{array}{l}\text { (i) Increase salt } \\
\text { content }\end{array}$ & \multicolumn{1}{c}{ Not obvious } & (i) Increase the leaf area index of crop \\
\hline $\begin{array}{c}\text { Irrigation } \\
\text { district }\end{array}$ & $\begin{array}{l}\text { (i) Reduce } \\
\text { saline soil area }\end{array}$ & $\begin{array}{l}\text { (i) Lower groundwater } \\
\text { (ii) Increase river flow }\end{array}$ & $\begin{array}{l}\text { (i) Reduce canal farmland shelterbelt } \\
\text { (ii) Reduce natural farmland shelterbelt } \\
\text { (iii) Increase irrigated farmland shelterbelt } \\
\text { (iv) Reduce natural vegetation } \\
\text { (v) Increase river valley vegetation }\end{array}$ \\
\hline Watershed & $\begin{array}{l}\text { (i) Reduce } \\
\text { saline soil area }\end{array}$ & $\begin{array}{l}\text { (i) Lower groundwater level } \\
\text { in local region } \\
\text { (ii) Increase downstream } \\
\text { groundwater level } \\
\text { (iii) Increase river flow }\end{array}$ & $\begin{array}{l}\text { (i) Reduce local natural vegetation } \\
\text { (ii) Increase downstream natural vegetation } \\
\text { (iii) Increase river valley vegetation }\end{array}$ \\
\hline
\end{tabular}

\subsection{Groundwater Level and Surface Water Increment in Different Water-Saving Irrigation Scenarios}

Based on the simulation calculation of different water-saving irrigation scenarios, the response of the groundwater level in the irrigation district can be analyzed. Since large-scale water-saving irrigation reduces the amount of leakage replenishment in the water delivery process and the field irrigation process, the groundwater level will decline. The average groundwater level drops of observation wells in different scaled water-saving irrigation scenarios are shown in Figure 6. In the canal lining scenario (S-1), when the canal water utilization coefficients of each canal system were increased to 0.95 , the leakage replenishment in the canal system was reduced, then the average water level drop of the observation wells in the irrigation district was $0.18 \mathrm{~m}$. In the pipeline irrigation scenario (S-2), except for the Nangan Irrigation Area (NIA), the irrigation area proportions using underground water through pipeline of other irrigation areas were increased to $50 \%$, not only the leakage replenishment in the canal system decreased further, but also the groundwater pumping amount increased significantly. As a result, the average water level drop of the observation wells in the irrigation district will reach $0.61 \mathrm{~m}$. In the drip irrigation scenario (S-3), drip irrigation was used in the pipeline irrigation area. Although the amount of irrigation percolation in the field declined, the groundwater pumping amount was reduced at the same time, so the groundwater level was increased when compared with the pipeline irrigation scheme (S-2), and the average water level drop of the observation wells in the irrigation district was $0.59 \mathrm{~m}$. In the comprehensive scenario (S-4), the canal water utilization coefficients were increased, the canal leakage replenishment was further reduced, and the average water level drop of observation wells in the irrigation district was $0.69 \mathrm{~m}$.

The areas of different groundwater depth ranges in four typical scaled water-saving irrigation scenarios are shown in Figure 7. In the canal lining scenario (S-1), the area with a groundwater depth less than $5 \mathrm{~m}$ was reduced by $15.13 \mathrm{~km}^{2}$ compared with the S-0 scenario. The area with a groundwater depth less than $2 \mathrm{~m}$ decreased by $5.56 \%$, the area with a groundwater depth of $2-5 \mathrm{~m}$ decreased by $3.47 \%$, while that with a groundwater depth of $5-7 \mathrm{~m}$ increased by $0.61 \%$. In the pipeline irrigation scenario (S-2), the area with a groundwater depth less than $7 \mathrm{~m}$ was further reduced due to the large-scale groundwater pumping instead of the original canal irrigation using surface water, it was $40.94 \mathrm{~km}^{2}$ less than the S-0 scheme. Among them, the area with a groundwater depth less than $2 \mathrm{~m}$ decreased by $15.87 \%$, the area with a groundwater depth of $2-5 \mathrm{~m}$ decreased by $6.94 \%$, and the area with a groundwater depth of 5-7 $\mathrm{m}$ decreased by $1.84 \%$. In the drip irrigation scenario (S-3), the amount of groundwater pumping was reduced. Compared with the S-2 scenario, the area with 
a groundwater depth of 5-7 m did not change, while the area with a groundwater depth of 2-5 m increased by $2.67 \mathrm{~km}^{2}$. In the comprehensive scenario (S-4), the water-saving scale was the maximum in four scenarios, and the area with a groundwater depth less than $7 \mathrm{~m}$ obrained the minimum in all scenarios. Among them, the area with a groundwater depth less than $2 \mathrm{~m}$ was reduced by $15.87 \%$ compared with the S-0 scenario, the area with a groundwater depth of $2-5 \mathrm{~m}$ declined by $7.99 \%$, and the area with a groundwater depth of $5-7 \mathrm{~m}$ dropped by $3.07 \%$.

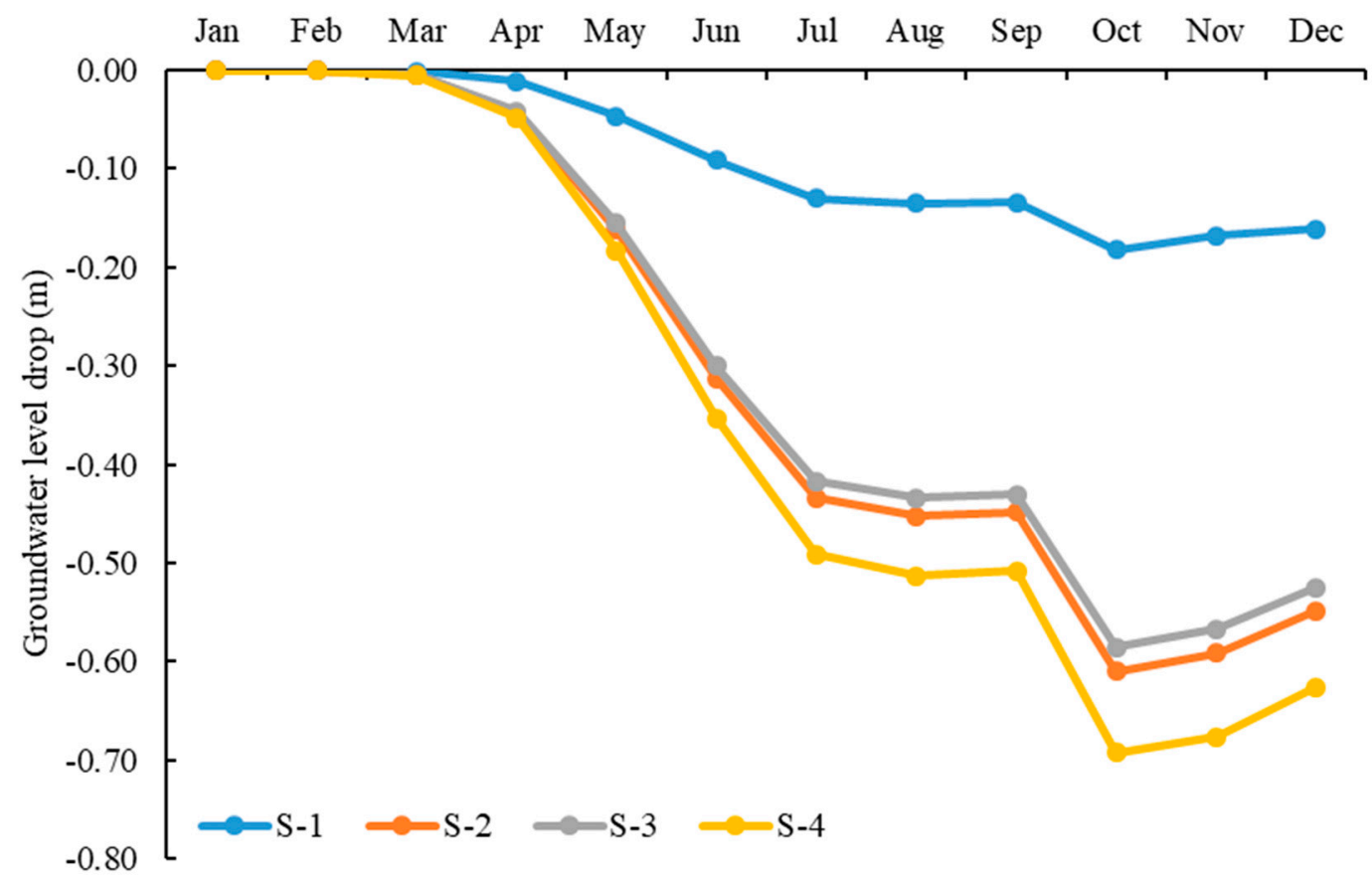

Figure 6. Average drops of groundwater level in four typical scaled water-saving irrigation scenarios.

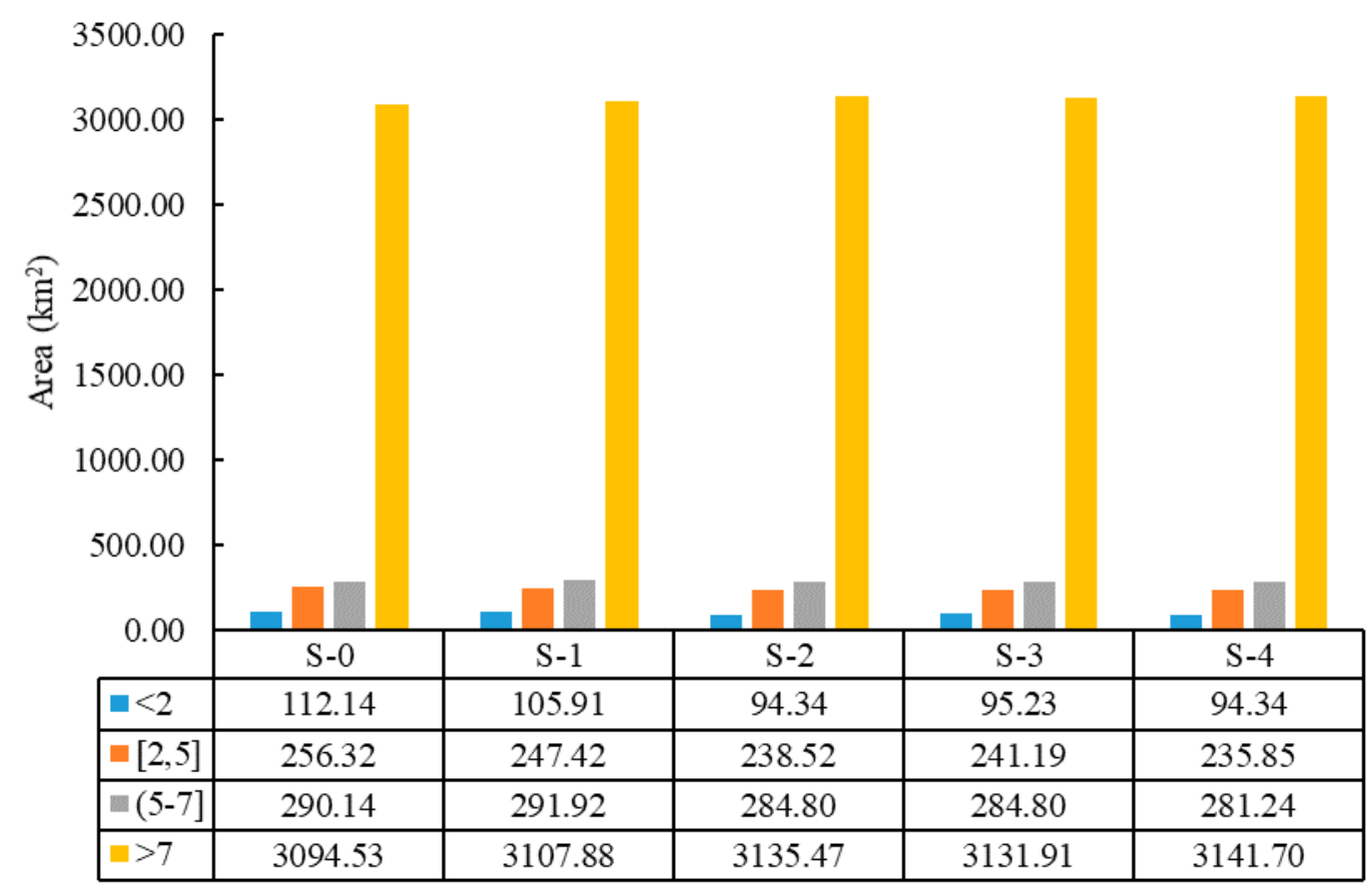

Figure 7. Areas of different groundwater depth ranges in scaled water-saving irrigation scenarios.

Due to the large leakage coefficient of the river channel in the middle reaches of the Shule River, most of the natural surface runoff will disappear in the Gobi Desert in the southern part of the study 
area. Therefore, a large amount of surface water is transported to the downstream areas through the lining canals, which is called the ecological water transport of surface water. The ecological water transport of surface water was 240 million $\mathrm{m}^{3}$ in 2017. Large-scale water-saving irrigation can greatly reduce the local irrigation water diversion from the river and transport more ecological water to the downstream areas. The increases of ecological water transfer in different scaled water-saving irrigation scenarios are shown in Figure 8. In the channel lining scenario (S-1), when the canal water utilization coefficients of each canal system were increased to 0.95 , the ecological flow would be increased by 76 million $\mathrm{m}^{3}$, an increase of $31.69 \%$. The water-saving amount of general main canal was the most, accounting for $34.24 \%$, similar to that in the Xigan Irrigation Area (XIA). Due to the small irrigated areas of the Zongyizhigan Irrigation Area (ZIA) and Nangan Irrigation Area (NIA), the amounts of water saved were small. In the pipeline irrigation scenario (S-2) and the drip irrigation scenario (S-3), except for the Nangan Irrigation Area (NIA), the irrigation area proportions using groundwater through pipeline of other irrigation areas were increased to $50 \%$. It would increase the ecological flow by 139 million $\mathrm{m}^{3}$, an increase of $58.16 \%$. Since S-3 was to implement drip irrigation on the groundwater pipeline irrigation area of S-2, which only affected the groundwater pumping amount and did not affect the surface water diversion, the surface water-saving amounts of the two scenarios were the same. Due to the large irrigated areas, the water-saving amounts of Xigan Irrigation Area (XIA) and Dongbeigan Irrigation Area (DIA) accounted for $53.79 \%$ and $42.18 \%$ respectively. In the comprehensive scenario (S-4), of which water-saving intensity was relatively the largest, the ecological flow would be increased by 196 million $\mathrm{m}^{3}$, an increase of $81.80 \%$.

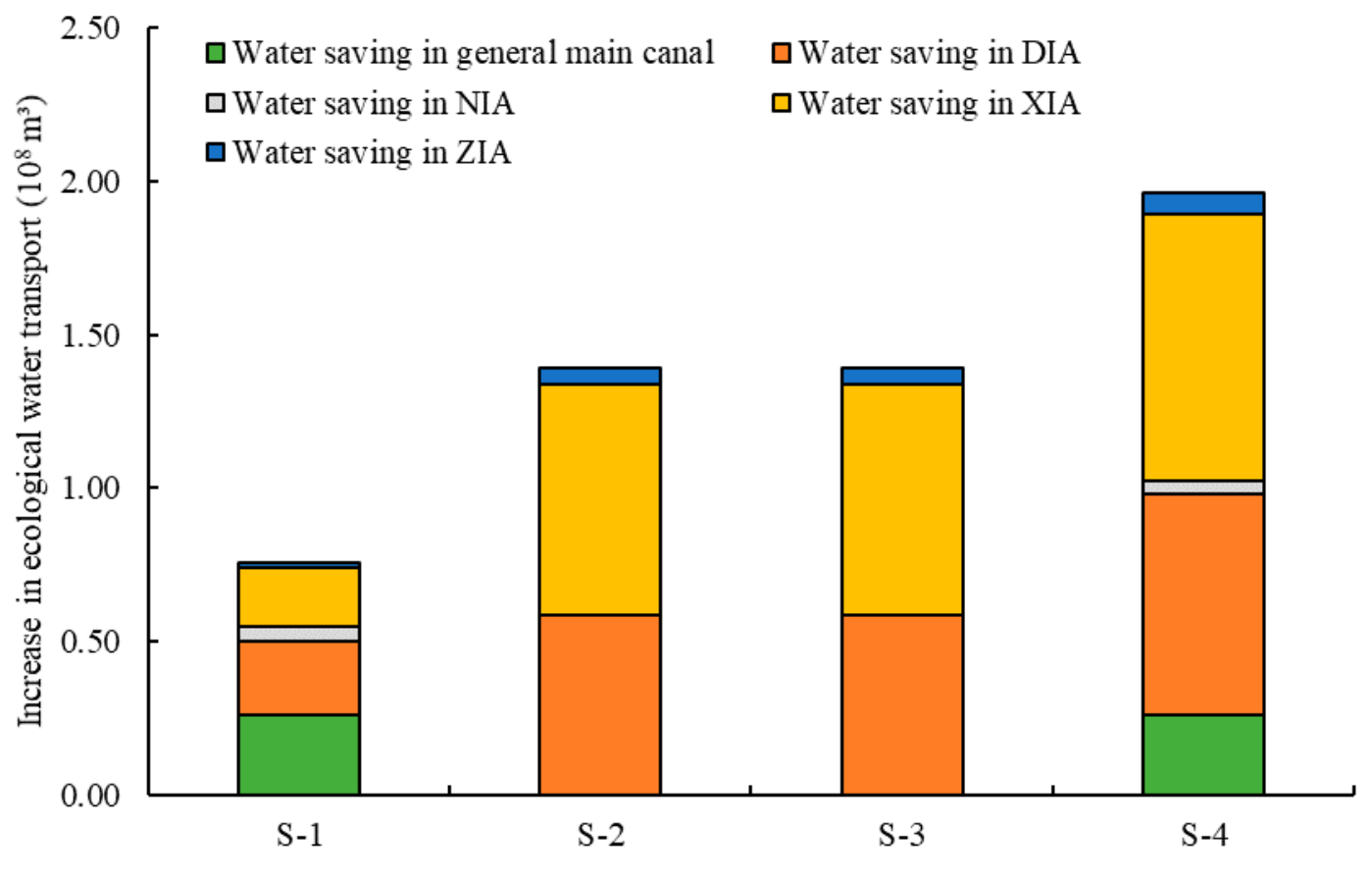

Figure 8. Increase of ecological water transfer in four typical scaled water-saving irrigation scenarios.

\subsection{Ecological Safety of Irrigation District in Different Water-Saving Irrigation Scenarios}

The ecological safety index in different scaled water-saving irrigation scenarios are shown in Table 8. With the implementation of large-scale water-saving irrigation, the ecological safety of irrigation district (ESI) declined, and the ESIs of four scenarios were ranked as follows: S-0 $>$ S-3 > S-4 $>$ S-1 > S-2. Water-saving irrigation improved the ecological safety of soil subsystem ( $\left.\mathrm{SESI}_{1}\right)$ due to the reduction of salinization-prone area. The reason why the $\mathrm{SESI}_{1}$ of the drip irrigation scenario (S-3) was slightly lower than that of the pipeline irrigation scenario (S-2) is that drip irrigation reduced the pumping volume and the groundwater level rose. As the saved agricultural water was returned to the 
river, the ecological safety of the surface water subsystem $\left(\mathrm{SESI}_{2}\right)$ was improved. In the comprehensive scenario (S-4), $\mathrm{SESI}_{2}$ was increased to 0.5488 . The ecological safety of the groundwater subsystem $\left(\mathrm{SESI}_{3}\right)$ decreased with the development of water-saving irrigation but increased in well irrigation areas, thus, the $\mathrm{SESI}_{3}$ of the drip irrigation scenario (S-3) was higher than the pipeline irrigation scenario (S-2). The ecological safety of biology $\left(\mathrm{SESI}_{4}\right)$ of four water-saving irrigation scenarios were lower than the current situation. With regard to farmland shelterbelt, the ecological safety of irrigated farmland shelterbelt (IFSS) increased with the increase of drip irrigation area; the canal-side farmland shelterbelt (CFSD) in the canal lining scenario (S-1) degraded due to the increase of the canal water utilization coefficient, and that in the pipeline irrigation scenario (S-2) and the drip irrigation scenario (S-3) deteriorated due to the replacement of the canals by the pipelines; the safety of the natural farmland shelterbelt (NFSS) was reduced due to the drop in the groundwater level caused by large-scale water-saving irrigation. When it comes to natural vegetation, as the river flow increased due to the scaled water-saving irrigation, the ecological safety of natural vegetation in the valley (RNVS) was improved, while that of natural vegetation far from the valley (GNVS) was reduced due to the reduced groundwater level.

Table 8. Ecological safety index in different scaled water-saving irrigation scenarios.

\begin{tabular}{|c|c|c|c|c|c|}
\hline Ecological Safety Index & S-0 & S-1 & S-2 & S-3 & S-4 \\
\hline ESI & 0.4902 & 0.4578 & 0.4550 & 0.4894 & 0.4666 \\
\hline (1) $\mathrm{SESI}_{1}$ & 0.0000 & 0.0702 & 0.1966 & 0.1826 & 0.1966 \\
\hline (2) $\mathrm{SESI}_{2}$ & 0.3019 & 0.3975 & 0.4774 & 0.4774 & 0.5488 \\
\hline (3) $\mathrm{SESI}_{3}$ & 1.0000 & 0.8264 & 0.6528 & 0.7049 & 0.6007 \\
\hline (4) $\mathrm{SESI}_{4}$ & 0.6588 & 0.5369 & 0.4933 & 0.5926 & 0.5204 \\
\hline 1) FSS & 0.6667 & 0.4213 & 0.3901 & 0.5745 & 0.4336 \\
\hline (i)IFSS & 0.0000 & 0.0000 & 0.0000 & 0.5000 & 0.5000 \\
\hline (ii)CFSD & 0.0000 & 0.5372 & 0.3787 & 0.3787 & 0.7084 \\
\hline (iii)NFSS & 1.0000 & 0.8011 & 0.5491 & 0.6021 & 0.5093 \\
\hline 2) NVS & 0.6509 & 0.6525 & 0.5965 & 0.6107 & 0.6073 \\
\hline (i)RNVS & 0.3019 & 0.3975 & 0.4774 & 0.4774 & 0.5488 \\
\hline (ii) GNVS & 1.0000 & 0.9075 & 0.7155 & 0.7440 & 0.6657 \\
\hline
\end{tabular}

\section{Discussion}

In the Results section, we showed the ecological safety of water-saving irrigation at different scales. In fact, it is worth noting that, for different irrigation water sources, the effects of large-scale water-saving irrigation on groundwater are completely opposite. For the canal irrigation districts using surface water, water-saving irrigation reduces the leakage of the canal and percolation in the field, resulting in a downward trend in the groundwater level. However, for well irrigation districts using groundwater, water-saving irrigation can reduce the amount of groundwater pumping and alleviate groundwater over-exploitation. For the districts where canal irrigation is carried out using surface water, the ecological effects of large-scale water-saving irrigation are different when the initial groundwater level conditions are different. For the canal irrigation district with a shallow groundwater depth, such as the Hetao Irrigation District in the Yellow River Basin, large-scale water-saving irrigation is conducive to reducing the groundwater level and reducing the intensity of phreatic evaporation, which can effectively alleviate the problem of soil salinization in the irrigation district and have a positive effect on the growth and development of crops and natural vegetation. However, there is a threshold for the scale of the water-saving irrigation application. The lowered groundwater level should not be lower than the maximum depth for the survival of natural vegetation. Otherwise, it will seriously affect the living environment of the natural vegetation around the irrigation district, resulting in the degradation of natural vegetation communities. For the canal irrigation district with deep groundwater depth, such as the Changma Irrigation District in the Shule River Basin, the large amount of leakage in the canal and percolation in the field brought by traditional irrigation is an 
important source of groundwater. The raised groundwater level caused by irrigation makes the area around the irrigation district where there was no natural vegetation in the past begin to grow vegetation and become part of the artificial oasis. However, as the irrigated district continues to expand, the flow of the river taken by local agricultural irrigation is increasing, and the extent of artificial oasis continues to develop, while it will cause the shrinking or even degradation of downstream natural oases. The developments of artificial oases and natural oases present an inevitable competitive relationship. In these irrigation districts where the groundwater level was originally deep but increased by irrigation, large-scale water-saving irrigation will lead to a decline in the groundwater level, which inevitably affects the natural vegetation of the artificial oasis. However, it should not be abandoned to develop water-saving irrigation. In this case, the ecological safety of large-scale water-saving irrigation should be comprehensively considered at the regional or even basin scale. The artificial oasis is developed after taking the water resources of the natural oasis, therefore, it is reasonable to return some of the ecological flow to the downstream natural oasis by implementing water-saving irrigation in the local irrigation district. Therefore, by developing water-saving irrigation and setting a warning scale threshold, it can not only transport more ecological flow for the downstream ecology, but also prevent the natural vegetation of the artificial oasis from extensive degradation, ensuring the sustainable development of the natural and artificial oases.

The groundwater level in the four typical water-saving irrigation scenarios in this study declined due to the reduced canal leakage and field percolation. Xu et al. [34] reported that the upgrade of the canal system in Hetao Irrigation District in Northwest China might lower the groundwater level by $0.28-0.48 \mathrm{~m}$, and higher declines of the groundwater table were predicted when the canal system was upgraded and water-saving measures in the field were implemented at the same time, which are similar to the results of this paper. Yue et al. [11] studied the impact of water saving measures on groundwater balance in large-scale arid irrigation district, and found that the impact of lining canals and water-saving measures in field on the groundwater level reduction was limited, while the combined use of surface and groundwater resources would lead to greater drop in the groundwater table. This paper achieved similar research results, the area with a groundwater depth less than $7 \mathrm{~m}$ in pipeline irrigation scenario (S-2) using underground water was reduced drastically when compared with the canal lining scenario (S-1). Due to the reduction in irrigation water diversion from the river, the ecological flow in the four typical water-saving irrigation scenarios in this study were increased. These results are similar to that of Yue et al. [11] who reported that the combination of canal lining, water-saving measures in field and conjunctive use of water sources can reduce surface water flow by almost 52\%, which can be used to supply industrial sectors or improve the ecological environment. Yue and Zhan [35] found that the water diversion from the Yellow River can be reduced to the national limit amount of $4.0 \times 10^{9} \mathrm{~m}^{3} / \mathrm{a}$ by increasing the well-canal irrigated area and conjunctive use of surface and groundwater. In this study, it was also found that increasing the area of pipeline irrigation using groundwater can greatly reduce the irrigation water diversion from the river. The ecological safety of soil subsystem $\left(\mathrm{SESI}_{1}\right)$ in this study was improved by water-saving irrigation due to the reduction of the salinization-prone area. Similar results were reported by Yu et al. [36] who used satellite remote sensing images to analyze the trend of soil salinization in irrigation district. It was found that groundwater depth was the main factor leading to salt accumulation, and the water-saving project can significantly reduce the area of soil salinization in the irrigation district.

Water-saving irrigation is usually a combination of various types of water-saving technologies, but this paper focused on the engineering technologies, and did not consider the agronomic technologies and management technologies in detail. It is recommended that future research carry out more research on ecological safety considering different combinations of three types of water-saving irrigation technologies. In addition, in the water cycle simulation of the Changma Irrigation District, the input was based on the actual water diversion data of the study area. The complex crop planting structure and the rotation irrigation system of the irrigation district were not considered. Future research can carry out more water cycle simulations of irrigation district considering complex crop planting structures and rotational irrigation systems. 


\section{Conclusions}

This paper analyzed the positive and negative ecological effects of water-saving irrigation and the scale effects at four scales: plant, field, irrigation district, and watershed. In addition, the ecological safety of large-scale water-saving irrigation under different water sources and groundwater levels was discussed. A quantitative evaluation method based on Vensim and GMS models was proposed, which can enrich the theory of ecological safety of large-scale water-saving irrigation. The warning scale of large-scale water-saving irrigation was set as the scale when the area of local ecologically suitable groundwater depth decreased by no more than $20 \%$. In order to control the secondary salinization of the soil and protect the natural ecological vegetation, the ecologically suitable groundwater depth in arid inland river basin was set at 2-5 m. The Changma Irrigation District in the arid inland river basin of Northwest China was taken as an example to carry out the research to evaluate the ecological safety of large-scale water-saving irrigation. The ecological safety of four typical scenarios of large-scale water-saving irrigation (canal lining scenario, pipeline irrigation scenario, drip irrigation scenario, and comprehensive scenario) was quantitatively analyzed. It has positive significance for guiding the sustainable development of water-saving irrigation and ecological environment protection in the study area and other arid inland river basins.

The results showed that large-scale water-saving irrigation will reduce the amount of leakage in the canal system and percolation in the field, then the groundwater level in the irrigation district will decline, but at the same time it can reduce salinization-prone area in the irrigation district and transport more ecological flow for the downstream area. With the implementation of large-scale water-saving irrigation, the ecological safety of irrigation district (ESI) declined, and the ESIs of four scenarios were ranked as follows: S-0 > S-3 > S-4 > S-1 > S-2. Water-saving irrigation improved the ecological safety of soil subsystem $\left(\mathrm{SESI}_{1}\right)$ due to the reduction of salinization-prone area, and improved that of the surface water subsystem $\left(\mathrm{SESI}_{2}\right)$ since more water was returned to the river. The ecological safety of groundwater subsystem $\left(\mathrm{SESI}_{3}\right)$ decreased with the development of water-saving irrigation but increased in well irrigation areas. The ecological safety of biology $\left(\mathrm{SESI}_{4}\right)$ of four water-saving irrigation scenarios were lower than the current situation. The ecological safety of the irrigated farmland shelterbelt (IFSS) increased with the increase of the drip irrigation area, and the canal-side farmland shelterbelt (CFSD) deteriorated due to the reduction of canal leakage, while the safety of the natural farmland shelterbelt (NFSS) was reduced because of the drop in the groundwater level. The ecological safety of natural vegetation in the valley (RNVS) was improved, while that of natural vegetation far from the valley (GNVS) was reduced by the reduced groundwater level.

Author Contributions: The idea and method for the study were proposed by G.J. and Z.W., and G.J. performed the simulation calculation and result analysis. G.J. and Z.W. wrote the article and contributed to the article's discussion. Funding acquisition: Z.W.; methodology: G.J. and Z.W.; supervision: Z.W.; writing一original draft, G.J.; writing—review and editing: G.J. and Z.W.

Funding: This research was funded by the National Key Research and Development Plan Project of China (No. 2016YFC0402900) and the Key Research and Development and Transformation Plan Project of Qinghai Province of China (No. 2017-SF-116).

Acknowledgments: We thank the Water Resources Bureau of Shule River Basin for providing the data required and appreciate the editors and reviewers for providing thorough and constructive comments to improve our manuscript.

Conflicts of Interest: The authors declare no conflict of interest.

\section{References}

1. United Nations World Water Assessment Programme. The United Nations World Water Development Report 2018: Nature-Based Solutions for Water; UNESCO: Paris, France, 2018.

2. Belder, P.; Bouman, B.; Cabangon, R.; Lu, G.; Quilang, E.; Li, Y.H.; Spiertz, J.; Tuong, T.P. Effect of water-saving irrigation on rice yield and water use in typical lowland conditions in Asia. Agric. Water Manag. 2004, 65, 193-210. [CrossRef] 
3. Jaegermeyr, J.; Gerten, D.; Heinke, J.; Schaphoff, S.; Kummu, M.; Lucht, W. Water savings potentials of irrigation systems: Global simulation of processes and linkages. Hydrol. Earth Syst. Sci. 2015, 19, 3073-3091. [CrossRef]

4. Thompson, T.L.; Pang, H.; Li, Y. The potential contribution of subsurface drip irrigation to water-saving agriculture in the Western USA. Agric. Sci. China 2009, 8, 850-854.

5. Qi, X.; Pang, H. Present situation of research on the impact of water-saving irrigation on farmland ecological environment and major problems. Trans. Chin. Soc. Agric. Eng. 2000, 16, 37-40. (In Chinese)

6. Lei, B.; Liu, Y.; Du, L.; Wang, L.; Peng, Z. Primary research on integrated evaluation of environment impacts by water-saving improvement in irrigation districts. J. Irrig. Drain. 2011, 30, 100-103. (In Chinese)

7. Tyagi, L.; Kumari, B.; Singh, S.N. Water management-A tool for methane mitigation from irrigated paddy fields. Sci. Total Environ. 2010, 408, 1085-1090. [CrossRef] [PubMed]

8. Mishra, S.; Rath, A.K.; Adhya, T.K.; Rao, V.R.; Sethunathan, N. Effect of continuous and alternate water regimes on methane efflux from rice under greenhouse conditions. Biol. Fertil. Soils 1997, 24, $399-405$. [CrossRef]

9. Liu, X.; Wang, C.; Xu, X. Discussion on the influence of water-saving irrigation on ecological environment. Huaihe River Gov. 2002. (In Chinese) [CrossRef]

10. Camp, C.R. Subsurface drip irrigation: A review. Trans. ASAE 1998, 41, 1353-1367. [CrossRef]

11. Yue, W.; Liu, X.; Wang, T.; Chen, X. Impacts of water saving on groundwater balance in a large-scale arid irrigation district, Northwest China. Irrig. Sci. 2016, 34, 297-312. [CrossRef]

12. Pereira, L.S.; Goncalves, J.M.; Dong, B.; Mao, Z.; Fang, S.X. Assessing basin irrigation and scheduling strategies for saving irrigation water and controlling salinity in the upper Yellow River Basin, China. Agric. Water Manag. 2007, 93, 109-122. [CrossRef]

13. Lu, Y. Impact of water saving agriculture development on farmland shelterbelt. Agric. Technol. 2016, 36, 67-68. (In Chinese)

14. Luo, Y. Long-term effects of drip irrigation on soil salinization in arid area. Sci. China (Terrae) 2014, 44, 1679-1688. (In Chinese)

15. Liu, Z.; Zhang, Z.; Li, Y.; Cui, Y. Environmental impact assessment of water-saving irrigation projects. Water Sav. Irrig. 2003. (In Chinese) [CrossRef]

16. Grafton, R.Q.; Williams, J.; Perry, C.J.; Molle, F.; Ringler, C.; Steduto, P.; Udall, B.; Wheeler, S.A.; Wang, Y.; Garrick, D.; et al. The paradox of irrigation efficiency. Science 2018, 361, 748-750. [CrossRef] [PubMed]

17. Hanjra, M.A.; Qureshi, M.E. Global water crisis and future food security in an era of climate change. Food Policy 2010, 35, 365-377. [CrossRef]

18. Jiang, Y. China's water security: Current status, emerging challenges and future prospects. Environ. Sci. Policy 2015, 54, 106-125. [CrossRef]

19. Stoate, C.; Baldi, A.; Beja, P.; Boatman, N.D.; Herzon, I.; van Doorn, A.; de Snoo, G.R.; Rakosy, L.; Ramwell, C. Ecological impacts of early 21st century agricultural change in Europe-A review. J. Environ. Manag. 2009, 91, 22-46. [CrossRef]

20. Shen, Z.; Xu, D.; Li, L.; Wang, J.; Shi, X. Ecological and health risks of heavy metal on farmland soils of mining areas around Tongling City, Anhui, China. Environ. Sci. Pollut. Res. 2019, 26, 15698-15709. [CrossRef]

21. Jerrentrup, J.S.; Dauber, J.; Strohbach, M.W.; Mecke, S.; Mitschke, A.; Ludwig, J.; Klimek, S. Impact of recent changes in agricultural land use on farmland bird trends. Agric. Ecosyst. Environ. 2017, 239, 334-341. [CrossRef]

22. Kleczkowski, A.; Ellis, C.; Hanley, N.; Goulson, D. Pesticides and bees: Ecological-economic modelling of bee populations on farmland. Ecol. Model. 2017, 360, 53-62. [CrossRef]

23. Kleijn, D.; Sutherland, W.J. How effective are European agri-environment schemes in conserving and promoting biodiversity? J. Appl. Ecol. 2003, 40, 947-969. [CrossRef]

24. Cole, L.J.; Mccracken, D.I.; Dennis, P.; Downie, I.S.; Griffin, A.L.; Foster, G.N.; Murphy, K.J.; Waterhouse, T. Relationships between agricultural management and ecological groups of ground beetles (Coleoptera: Carabidae) on Scottish farmland. Agric. Ecosyst. Environ. 2002, 93, 323-336. [CrossRef]

25. Aliyari, F.; Bailey, R.T.; Tasdighi, A.; Dozier, A.; Arabi, M.; Zeiler, K. Coupled SWAT-MODFLOW model for large-scale mixed agro-urban river basins. Environ. Model. Softw. 2019, 115, 200-210. [CrossRef] 
26. Hadded, R.; Nouiri, I.; Maßmann, J.; Huber, M.; Laghouane, A.; Yahiaoui, H.; Tarhouni, J. A Decision Support system to manage the groundwater of the Zeuss Koutine Aquifer using the WEAP-MODFLOW framework. Water Resour. Manag. 2013, 27, 1981-2000. [CrossRef]

27. Xu, X.; Huang, G.; Qu, Z.; Pereira, L.S. Using modflow and GIS to assess changes in groundwater dynamics in response to water saving measures in irrigation districts of the Upper Yellow River Basin. Water Resour. Manag. 2011, 25, 2035-2059. [CrossRef]

28. Eberlein, R.L.; Peterson, D.W. Understanding models with vensim. Eur. J. Oper. Res. 1992, 59, $216-219$. [CrossRef]

29. Abadi, L.S.K.; Shamsai, A.; Goharnejad, H. An analysis of the sustainability of basin water resources using Vensim model. KSCE J. Civ. Eng. 2015, 19, 1941-1949. [CrossRef]

30. Alaviani, F.; Sedghi, H.; Moghaddam, A.A.; Babazadeh, H. Adopting GMS-PSO Model to Reduce Groundwater Withdrawal by integrated water resources management. Int. J. Environ. Res. 2018, 12, 619-629. [CrossRef]

31. Parhizkar, S.; Ajdary, K.; Kazemi, G.A.; Emamgholizadeh, S. Predicting water level drawdown and assessment of land subsidence in Damghan aquifer by combining GMS and GEP models. Geopersia 2015, 5, 63-80.

32. Edmunds, W.M.; Ma, J.; Aeschbach-Hertig, W.; Kipfer, R.; Darbyshire, D.P.F. Groundwater recharge history and hydrogeochemical evolution in the Minqin Basin, North West China. Appl. Geochem. 2006, 21, 2148-2170. [CrossRef]

33. Ma, J.; Edmunds, W.M. Groundwater and lake evolution in the Badain Jaran desert ecosystem, Inner Mongolia. Hydrogeol. J. 2006, 14, 1231-1243. [CrossRef]

34. Xu, X.; Huang, G.; Qu, Z.; Pereira, L.S. Assessing the groundwater dynamics and impacts of water saving in the Hetao Irrigation District, Yellow River basin. Agric. Water Manag. 2010, 98, 301-313. [CrossRef]

35. Yue, W.; Zhan, C. A large-scale conjunctive management model of water resources for an arid irrigation district in China. Hydrol. Res. 2013, 44, 926-939. [CrossRef]

36. Yu, R.; Liu, T.; Xu, Y.; Zhu, C.; Zhang, Q.; Qu, Z.; Liu, X.; Li, C. Analysis of salinization dynamics by remote sensing in Hetao Irrigation District of North China. Agric. Water Manag. 2010, 97, 1952-1960. [CrossRef]

(C) 2019 by the authors. Licensee MDPI, Basel, Switzerland. This article is an open access article distributed under the terms and conditions of the Creative Commons Attribution (CC BY) license (http://creativecommons.org/licenses/by/4.0/). 